which the ministry wanted to introduce into the bill, without the consent of the academic community. In particular, the academics said, the ministry had tried:

- To limit academic freedom.

- To restrict the autonomy of the universities in disposing of their financial resources.

- To extend the competence of the courts over students' organizations.

- To limit the right of workers in academic institutions to protest against discussions.

- To return to the former system of selection of university rectors, deans and collegiate bodies.

These amendments, the academics maintain, would virtually nullify the liberalization of academic life introduced in the past year which the bill was supposed merely to codify.

After a number of meetings with academics - and a stormy press confer-

\section{Hidden spectre}

Doubts have emerged about the validity of some important claims in photosynthesis research based on experiments carried out by Mr Mark Spector, much of whose recent work on protein kinases in relation to tumour viruses has been retracted by his erstwhile boss, Professor E. Racker of Cornell University (see Nature 10 September, p.93).

A paper published in the Proceedings of the National Academy of Sciences in February 1980 by Spector and C. Douglas Winget produced a considerable impact because it reported the purification from chloroplasts of the long sought-after enzyme responsible for the photosynthetic splitting of water to release oxygen. Other laboratories which hastened to confirm and extend this finding found difficulty in repeating the published experiments but, particularly when Spector ascended to the respectability of Racker's laboratory, these difficulties were put down to nothing more than the everyday problems of reproducibility of much biochemical work. Inevitably, however, there are now questions about the validity of the Spector and Winget claim as well as about an extension of the work reported by $\mathrm{Dr}$ Winget at the Fifth International Photosynthesis Congress held in Greece in September 1980.

Dr Winget, who did postdoctoral work with Professor Racker, is in the painful process of checking the experiments he published with Spector. Perhaps because he has not yet had time to check everything, the picture is confusing and not altogether comforting. Although he can repeat some parts, there are others which, despite considerable effort, he has been unable to reproduce. Dr Winget, reached by telephone on Monday afternoon, was afterwards unavailable.

Peter Newmark ence with educational journalists on 15 September - the minister found himself facing a number of "strike alerts" from academics and students, due to take effect when the academic year opens on 1 October. Although the majority of protest messages stressed the academics' desire for peaceful negotiation, some hard-liners were less amenable. In particular, the Independent Students' Association at Poznan Technical University called for all negotiations with the ministry to be called off. The only bill to go forward to the Sejm (Parliament) for ratification, they said, should be that drawn up by the Codification Commission; Minister Nawrocki has now promised to put this bill before the Council of Ministers. However, he is adding an appendix giving the ministry's own views on disputed points. In particular, says Nawrocki:

- The minister should have the right to set an upper limit on university intake "so as to ensure a rational employment policy.

- The university, as a budgetary unit, cannot have the right "freely to shape its pay fund", but must shape employment within the framework of the pay fund allocated.

- The rector should have the right to call for the dissolution of an assembly on university premises if it infringes public order or strikes at the political and social system of the state.

- Academic staff should have six weeks vacation, not eight.

- Rectors should be elected either by the university senate or electoral college, or by the senate and college in conjunction, as envisaged by the university statute.

In fact, some of these points were never in dispute. The academics had sought only budgetary autonomy within the funds allotted, not for unlimited funding. Nobody had questioned that the rector might need to call for help to quieten a disorderly assembly; what was agreed in the Lodz accords which settled last winter's student unrest was that the police should not come onto a campus uninvited.

The idea of an upper limit on university intake is reasonable enough, since Poland now faces the grim possibility of up to 1 million unemployed if the economy is to be made to balance, and the Prime Minister, General Wojciech Jaruzelski, has committed his government not to pay unemployment relief.

If such a policy is to be implemented, however, the present atmosphere of academic autonomy would suggest that it should be agreed by the various rectors and senates concerned, acting through the new Permanent Conference of Polish Universities, not sprung on them suddenly.

This, in fact, remains the bone of contention - the fact that the ministry tried to introduce the changes unilaterally and with virtually no time left for academics to voice objections. In spite of the minister's statement, therefore, the tension continues.

Vera Rich

\section{Research sponsorship \\ Agony at MIT}

Faculty members of the Massachusetts Institute of Technology (MIT) are holding a special meeting today (Thursday) to discuss a controversial offer from Mr Edwin (Jack) Whitehead, the founder and former president of the laboratory instrument company Technicon Corporation, to fund a free-standing institute for research into molecular approaches to developmental biology.

Under the terms of the offer, \$20 million would be provided for the construction of a building in Cambridge to house the Whitehead Institute for Biomedical Research, which has already been formed, with Dr David Baltimore, at present American Cancer Society Professor of Microbiology at MIT, as its director.

Mr Whitehead will also provide an initial $\$ 5$ million a year to cover the running costs of the institute, enough to support 20 new research professors. MIT would receive an additional endowment of $\$ 7.5$ million to cover costs associated with its links to the institute, and eventually the Whitehead Institute would be provided with its own endowment of $\$ 100$ million to guarantee a permanent income.

Top administrators at MIT are enthusiastic about Mr Whitehead's proposals, which they see as maintaining MIT as one of the leading biotechnology research institutions on the East Coast.

\section{Commission man}

The European Commission has appointed an outsider as director-general of Research, Science and Education (DG XII) in succession to Dr G. Schuster, who resigned in August after a nine year stint. Paolo Fasella, professor of biochemistry at the University of Rome, takes over the post on 1 October.

Professor Fasella is, however, well versed in European research policy. He has been involved in the running of the European Molecular Biology Laboratory and in the years 1975-79 was president of the European Molecular Biology Conference. He has also served on various committees dealing with research policy in energy and biotechnology both at a European level and in his native Italy. Since 1973 he has been an adviser to the Italian government on such matters and has taken a particular interest in the problems of relating research results to industry.

One of Professor Fasella's first tasks in his new appointment will be to formulate a revised research strategy for the commission. In particular he will be devising the four-year indirect action programme which begins in 1983 .

Professor Fasella's research work has been mainly in enzymology.

Judy Redfearn 
However, the proposal has generated some controversy among faculty members over how compatible a virtually autonomous research institute would be with traditional academic practices. And the MIT debate is being watched closely by other research universities .

In the case of the Whitehead Institute, the debate has focused on the implications of the "dual allegiance" of the research staff. These will have joint appointments between the institute and MIT, and although the staff will be appointed and paid by the Whitehead Institute, MIT's own research and review procedures for recruitment would apply.

However, at a faculty meeting last month, several members asked whether academic staff paid for entirely by outside funds would participate fully in activities not directly related to their research, such as undergraduate teaching or participation on administrative committees.

Responding to some of these concerns, the Whitehead Institute has agreed that three MIT representatives should be appointed to its board of trustees - these are former president Jerome B. Wiesner, dean Abraham Siegel of the MIT Management School and Dr W. Gerald Austen, chief of surgical services at the Massachusetts General Hospital. Other trustees include Dr Donald Fredrickson, past director of the National Institutes of Health, and three members of the Whitehead family.

In a letter sent to faculty members before the September meeting, Dr Low said that he and president Paul Gray had concluded that the benefits of the proposed arrangement for MIT seem to outweigh the potential problems.

At the faculty meeting itself, Dr Baltimore answered critics of the proposal by saying that he intended to make sure that staff members of the Whitehead Institute fully participated in activities apart from teaching.

In reply to a question about the decision by Duke University in North Carolina to turn down a similar offer from $\mathrm{Mr}$ Whitehead to fund an independent research institute seven years ago, Dr Low said that at the time Mr Whitehead's ideas had been more medically oriented. Having discussed the Duke decision with its president, Mr Terry Sanford, he said that he was convinced that there was nothing in the decision to deter a possible MIT affiliation.

The MIT Corporation, which is formally responsible for the affairs of MIT, will discuss Mr Whitehead's of fer at its meeting tomorrow. Any conclusions reached or recommendations made at today's faculty meeting will be passed on to the corporation, although a spokesman for MIT said last week that he does not anticipate any substantial opposition.

It is intended that the Whitehead Institute should be independent of commercial interests. Although, like MIT, it will have patent rights to the results of its own research, no company will have preferential right to the licences. A final decision is expected at the corporation's meeting in December.

David Dickson

\section{UK industry fights genetic guidelines}

British industry is unlikely to be satisfied by the relaxation of guidelines for the industrial application of genetic manipulation which the Genetic Manipulation Advisory Group (GMAG) plans to approve this week. The new guidelines have been through several drafts since they were first discussed earlier this year. The latest draft removes the present obligation on industry to give warning when it plans to use cultures of more than 10 litres when laboratory-scale experiments with the microorganisms are exempt from notification. Instead, companies would be required to notify the group only at the start of their operations. But notification of large-scale operations with organisms classified for laboratory purposes in category 1 or above would still have to be given well in advance.

The spur for revising the guidelines came earlier in the year, when the Confederation of British Industry (CBI) produced its own recommendations. In particular, it urged that processes using microorganisms exempt from regulation at the laboratory level should be exempt from notification, and that notification alone should be sufficient for large-scale operations with category 1 micro- organisms. In all cases, the confederation argued, the same basis should be used for the assessment of large-scale and laboratory manipulation, but GMAG does not agree.

CBI's proposals echo its longstanding discontent with GMAG as such. Thus the confederation has urged that processes using microorganisms in higher categories of containment should be controlled by the newly reconstituted Advisory Committee on Dangerous Pathogens, on the grounds that too many regulatory bodies are involved, but also on the grounds of confidentiality. It also suggests that GMAG should transfer its responsibilities to the Health and Safety Executive, which should recruit its own staff inspectors and, when necessary, take advice from the Dangerous Pathogens Committee.

CBI's recommendations would effectively rob GMAG of control of industrial processes. GMAG's members, however, believe that the group should at least be aware of all new activities. The likely outcome is that GMAG's draft guidelines will be approved but that the dissenting voice of CBI will ensure that the debate continues. Judy Redfearn

\section{European space industry}

\section{Landing platform}

The European Parliament is urging the community of ten to formulate a long-term strategy for developing Europe's fledgling space industry. Last week, members of the parliament adopted a resolution calling for the speedy development of new space technologies that could enable Europe to compete with the United States space shuttle. In a vote that broadly endorsed the recommendations of a working document prepared by $\mathbf{M}$. André Turcat, a French member of the parliament and an exConcorde test pilot, they also called for a conference of European space ministers at the earliest opportunity.

The parliament's initiative is slightly unusual. Space policy has been largely left to those nations that have their own programmes and the members of the European Space Agency (ESA), not all of whom belong to the European Community. The initiative, however, comes at a time when the space agency is battling with the task of resolving national differences in drawing up a medium-term plan. The politicians are anxious that Europe should make a greater and more united effort.

M. Turcat argues in his document that the effort should be directed to competing in the growing world market for applications satellites and the vehicles to launch and even recover them. $\mathrm{He}$ estimates that the European space industry will grow to at least 10,000 million European units of account ( 1 EUA =

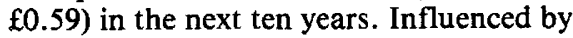
the recent decision of the National Aeronautics and Space Administration to cancel its contribution to the International SolarPolar Mission, he also argues for greater European independence.

That could be achieved, the document claims, if Europe were to develop technologies for establishing space stations and building unmanned, reusable vehicles capable of servicing them. Such a view will hearten members of the French national space agency, CNES, which is shortly to submit to ESA a proposal for a partly reusable launch vehicle. But enthusiasm from other quarters may be muted. Not all members of ESA are keen to devote the agency's limited budget to such a costly project.

The differences, however, may be resolved if, as the document argues, more money is devoted to space. That will be for the individual governments to decide. But one possibility, suggested in the debate on the document, is that the European Investment Bank should step in.

Such a major project would also involve some reorganization within the European space industry and possibly extending the role of ESA. While acknowledging that cooperation between Europe's diverse space industries has come a long way in the past six years, the document calls for even greater cohesion, suggesting collaboration 